\title{
PENELITIAN KUALITAS AIR SUNGAI BALIAN, TABANAN, BALI TAHUN 2018
}

\author{
Ni Putu Rahayu Artini, Desak Putu Risky VA, Ni Kadek Mona Fujiastuti \\ Program Studi Teknologi Laboratorium Medik, IIK Medika Persada Bali \\ Email : rahayu_artini@yahoo.co.id
}

\begin{abstract}
ABSTRAK
Sungai Balian merupakan sungai yang dimanfaatkan sebagai sumber air bersih dan sarana penyucian serta pengobatan bagi masyarakat. Oleh karena itu perlu adanya upaya pengujian kualitas air sungai Balian. Sampling air Sungai Balian diambil di tiga lokasi, yaitu hulu, tengah, dan hilir. Parameter fisika yang dianalisis adalah suhu, warna dan TDS (Total Dissolve Solid), parameter kimia yang dianalisis adalah $\mathrm{pH}$, $\mathrm{BOD}_{5}, \mathrm{COD}$, phosfat, dan nitrat. Sedangkan parameter mikrobiologi yang dianalisis adalah E. coli dan total coliform. Hasil analisis air Sungai Balian bagian hulu memiliki ciri-ciri air keruh tidak berbau dan memiliki kadar TDS 630 ppm, pH 7,23; BOD 8,637; COD 10,231; phosfat 0,122 ppm; nitrat 2,765 ppm; E. Coli 30 MPN/100 mL; dan Total coliform 50 MPN/ $100 \mathrm{~mL}$. Air Sungai Balian bagian tengah memiliki hasil analisis air jernih tidak berbau dan memiliki kadar TDS 550 ppm, pH 7,03; BOD 3,901; COD 7,250; phosfat 0,096 ppm; nitrat 2,232 ppm; E. Coli $15 \mathrm{MPN} / 100 \mathrm{~mL}$; dan Total coliform $25 \mathrm{MPN} / 100 \mathrm{~mL}$. Sedangkan air Sungai Balian bagian hilir memiliki hasil analisis air agak keruh tidak berbau dan memiliki kadar TDS 510 ppm, pH 7,78; BOD 10,370; COD 20,890; phosfat 0,237 ppm; nitrat 3,163 ppm; E. Coli 89 MPN/100 mL; dan Total coliform 100 MPN/ 100 mL.Berdasarkan Peraturan Gubernur Bali No. 16 Tahun 2016.air Sungai Balian bagian hulu dan hilir dapat dikatagorikan sebagai air kelas III, hal ini dikarenakan parameter BOD yang tinggi yaitu 8,637 ppm dan 10,370 ppm. Untuk air Sungai Balian bagian tengah masuk dalam air kelas II yang peruntukannya untuk air minum setelah dilakukan pengolahan, karena parameter fisika, kimia, dan mikrobiologi tidak melebihi baku mutu air kelas II. Oleh karena itu, berdasarkan hasil uji laboratorium air Sungai Balian bagian tengah masih layak dipergunakan sebagai sarana pembersihan dan pengobatan sesuai kepercayaan masyarakat Hindu.
\end{abstract}

Kata kunci : Sungai Balian, kualitas air, TDS, $\mathrm{pH}, \mathrm{BOD}_{5}$, COD, phosfat, nitrat, E. Coli, total coliform.

\begin{abstract}
Balian river is used as a source of clean water, holistic and threatment for the community. The sampling of Balian River, Tabanan, Bali is taken in three locations, upstream, central part, and downstream. Physical parameters analyzed were temperature, color, and TDS (Total Dissolved Solids). Chemistry parameters analyzed were $\mathrm{pH}, \mathrm{BOD} 5, \mathrm{COD}$, phosphate, and nitrate. While the microbiological parameters analyzed were E. coli and total coliform. The upstream Balian River water analysis result has characteristic of turbid odorless water and has TDS 630 ppm, pH 7.23; BOD 8.637; COD 10.231; phosphate 0.122 ppm; nitrate $2.765 \mathrm{ppm}$; E. Coli $30 \mathrm{MPN} / 100 \mathrm{~mL}$; and Total coliform $50 \mathrm{MPN} / 100 \mathrm{~mL}$. The central Balian River water has a clear, odorless water analysis and has a TDS content of $550 \mathrm{ppm}, \mathrm{pH}$ 7.03; BOD 3.901; COD 7.250; phosphate $0.096 \mathrm{ppm}$; nitrate $2.232 \mathrm{ppm}$; E. Coli $15 \mathrm{MPN} / 100 \mathrm{~mL}$; and Total coliform $25 \mathrm{MPN} / 100 \mathrm{~mL}$. While the downstream Balian River water has a slightly turbid odorless water analysis and has a TDS content of 510 ppm, pH 7.78; BOD 10.370; COD 20.890; phosphate 0.237 ppm; nitrate 3.163 ppm; E. Coli $89 \mathrm{MPN} / 100 \mathrm{~mL}$; and Total coliform $100 \mathrm{MPN} / 100 \mathrm{~mL}$. Based on the standard, Balian river water upstream and downstream can be classified as class III water, this is because BOD parameters are high that is $8.637 \mathrm{ppm}$ and $10.370 \mathrm{ppm}$. For the water of Balian River, the middle part is included in class II water which is intended for drinking water after processing, because the parameters of physics, chemistry, and microbiology do not exceed the class II water quality standard. Therefor, based on the results of laboratory test, the central part of Balian Riveris suitable for use as of cleaning and threatment according to the beliefs of the Hindu community.
\end{abstract}

Keyword: Balian River, quality of air, TDS, $p H, B O D_{5}, C O D$, phosphate, nitrate, E. Coli, total coliform

\section{PENDAHULUAN}

Sumberdaya air merupakan sumberdaya alam yang mengalir (flowing resources) dan mempunyai dimensi lintas wilayah adminstratif pemerintahan. Sebagai salah satu komponen lingkungan hidup, air akan mempengaruhi dan dipengaruhi oleh komponen lingkungan hidup lainnya. Kualitas air yang baik akan memberikan manfaat yang baik bagi lingkungan hidup sehingga dapat memberikan manfaat bagi kesehatan masyarakat. 
Sebagai suatu sumberdaya alam milik bersama, sumberdaya air memiliki arti penting baik secara ekologis maupun sosial-ekonomi bagi kehidupan masyarakat. Pengembangan sumberdaya air haruslah dilaksanakan dengan pendekatan wilayah hidrologis, berdasarkan prinsip satu sungai, satu rencana, satu pengelolaan terpadu (Adiono, 1987).

Salah satu sumberdaya air yang memiliki arti penting bagi kehidupan masyarakat dan memiliki dimensi pemanfaatan yang luas adalah sungai dan laut. Banyak aktifitas masyarakat yang memanfaatkan sungai, mulai dari kegiatan pertanian, kebutuhan domestik, industri, transportasi bahkan rekreasi.

Namun demikian, pada kenyatannya sungai dan laut seringkali dimanfaatkan sebagai tempat pembuangan limbah domestik, industri, pertanian dan lain sebagainya, sehingga mengakibatkan mutu air menurun. Apabila pembuangan limbah dilakukan terus menerus ke dalam sungai ataupun badan perairan lainnya dapat menyebabkan pencemaran air dan rusaknya lingkungan badan perairan tersebut. Kondisi ini hampir dialami oleh seluruh kota - kota di dunia, termasuk Indonesia maupun di Bali

Demikian juga Kabupaten Tabanan sebagai pusat pemerintahan, pusat pendidikan, dan pusat perdagangan bagi Provinsi Bali menjadikan Kota Tabanan terus melakukan pembangunan untuk memenuhi berbagai sarana dan prasarana. Dampak positif yang ditimbulkan adalah memberikan lapangan pekerjaan, meningkatkan pendapatan masyarakat dan membantu perekonomian di Kota Tabanan.

Namun, hal ini tidak dapat mengabaikan timbulnya dampak negatif, yang berpengaruh pada kondisi Lingkungan di Kota Tabanan, yakni terjadi penurunan kualitas lingkungan di Kota Tabanan. Salah satu dampak yang ditimbulkan yaitu Pencemaran Air Sungai dan Laut, yang diakibatkan oleh adanya aktivitas industri, jasa, rumah sakit, industri kecil, dan limbah rumah tangga.

Bukan hanya di pusat kota, namun di daerah pedesaan mulai banyak bermunculan beberapa fasilitas untuk menunjang pariwisata seperti villa, rumah makan, aktivitas arung jeram, aktivitas off road, dan lain sebagainya. Pemanfaat beberapa objek wisata tersebut diantaranya adalah objek wisata alam berupa sungai. Di Tabanan, Bali ada beberapa sungai diantaranya adalah Sungai Ho, Sungai Balian, Sungai Saba, dan Sungai Daya.

Salah satu sungai tersebut adalah Sungai Balian. Sungai memiliki hulu di daerah Busung Biu, Buleleng dan bagian tengahnya berada di Kecamatan Pupuan, Tabanan. Masyarakat di sekitanya percaya dan memanfaatkan air sungai tersebut sebagai sarana penglukatan, atau yang dikenal dengan istilah pembersihan, baik untuk kebutuhan sehari-hari maupun untuk pembersihan sebagai pengobatan. Sedangkan bagian hilirnya berada di Kecamatan Selemadeg, Tabanan. Namun, belum adanya informasi mengenai kualitas air di Sungai Balian, yang ditinjau dari aspek kesehatan lingkungan.

Oleh karena itu, kegiatan pemantauan lingkungan hidup sangat penting dilaksanakan Salah satu upaya yang dapat dilaksanakan adalah melakukan kegiatan pengujian kualitas air. Pengujian kualitas air sungai Balian meliputi pengujian kualitas air sungai dari aspek fisika, kimia, dan mikrobiologis yaitu bagian hulu, tengah, dan hilir. Penelitian ini sebagai uji pendahuluan, sehingga ke depannya perlu dilakukan pemantauan secara berkala setiap tahunnya untuk mengetahui kualitas air Sungai Balian sebagai sumber air air bersih dan sarana pembersihan serta pengobatan bagi masyarakat.

\section{METODE}

Sampel Penelitian. Sampel yang digunakan pada penelitian ini adalah air Sungai Balian yaitu hulu di daerah Kecamatan Busung Biu, Buleleng; bagian tengah di Kecamatan Pupuan, Tabanan dan bagian hilir di Kecamatan Selemadeg, Tabanan.

Bahan Kimia dan Instrumentasi. Bahan-bahan kimia yang digunakan adalah yaitu akuades, larutan ferro ammonium sulfat, larutan kalium permanganat, larutan perak sulfat, indikator ferroin, larutan ammonium molybdat, asam askorbat, standar phosfat, standar nitrat, larutan asam klorida, larutan mangan sulfat, larutan alkali iodide azine, larutan kanji 1\%, dan larutan natrium sulfat. Peralatan yang digunakan pada penelitian ini terdiri dari peralatan gelas dan alat ukur. Peralatan gelas terdiri dari botol sampling, corong, gelas ukur 50 $\mathrm{mL}$, labu ukur $50 \mathrm{~mL}$, pipet ukur, pipet tetes, Erlenmeyer $250 \mathrm{~mL}$, dan tabung reaksi. Alat ukur yang digunakan adalah neraca analitik (Merk Matrix type Esj 210-4B), seperangkat alat spektrofotometer UV-Vis (Merk Amtast AMV11), dan seperangka alat titrasi.

\section{Prosedur Kerja}

Pengambilan sampel air. Sampel air diambil dari air Sungai Balian yaitu hulu di daerah Kecamatan Busung Biu, Buleleng; bagian tengah di Kecamatan Pupuan, Tabanan dan bagian hilir di Kecamatan Selemadeg, Tabanan. Di lokasi saat pengambilan sampel dilakukan pengukuran suhu dan pH. Sampel air kemudian dibawa ke laboratorium untuk pengujian. Analisis parameter fisika. Pengujian sifat fisika meliputi pemeriksaan parameter suhu, warna, dan TDS. 


\section{Analisis parameter kimia}

Pengukuran $\mathrm{pH}$. Pengukuran $\mathrm{pH}$ sampel air menggunakan $\mathrm{pH}$ meter dan diawali dengan melakukan kalibrasi menggunakan buffer $\mathrm{pH} 4,7$, dan 10. Kemudian lakukan pengukuran pada sampel air. Pengukuran $\mathrm{pH}$ dilakukan di lokasi sampling

Biochemical Oxygen Demand (BOD). Kadar BOD dianalisis dengan metode titrasi iodometri menggunakan larutan baku $\mathrm{Na}_{2} \mathrm{~S}_{2} \mathrm{O}_{3}$ dan dititrasi sampailarutan berwarna kuning muda lalu ditambahi larutan indikator kanji 1\%, dan dititrasi kembali hingga warna biru hilang menjadi warna kuning (SNI 01-3554, 2006).

Chemical Oxygen Demand (COD). Kadar COD dianalisis dengan metode titrasi argentometri dengan larutan standar $\mathrm{Fe}\left(\mathrm{NH}_{4}\right)_{2}\left(\mathrm{SO}_{4}\right)_{2}$ hingga berubah warna dari biru kehijauan menjadi coklat kemerahan. Pengukuran blanko dilakukan menggunakan akuades dengan cara yang sama (SNI 01-3554, 2006).

Phosfat $\left(\mathrm{PO}^{4-}\right)$. Kadar phosfat dianalisis dengan spektrofotometer UV-Vis pada panjang gelombang $630 \mathrm{~nm}$. Sampel air, lalu ditambahi $\left(\mathrm{NH}_{4}\right) \mathrm{MO}_{4}-\mathrm{H}_{2} \mathrm{SO}_{4}$ dan dimasukkan sedikit kristal asam askorbat. Larutan tersebut dihomogenkan dan dididihkan sampai terbentuk warna biru sempurna dan diukur absorbansinya (SNI 01-3554, 2006).

Nitrat $\left(\mathrm{NO}^{3-}\right)$. Kadar nitrat diukur dengan spektrofotometer UV-Vis pada panjang gelombang $275 \mathrm{~nm}$. Sampel ditambahi $\mathrm{HCl} 1 \mathrm{~N}$. dan dihomogenkan, dilakukan hal yang sama pada larutan standar dan blanko (SNI 01-3554, 2006).

Analisis parameter mikrobiologi (SNI 013554, 2006). Perhitungan total bakteri menggunakan motode Total Plate Count atau TPC (Hadiwiyoto, 2004). Untuk menghitung jumlah $E$. coli dan Total coliform pengenceran yang tepat dipersiapkan sesuai dengan compedium of methods for microbiological examination of water. Pengujian parameter mikrobiologi pada sampel air sungai dilakukan dengan mengukur sebanyak 5 mL sampel dimasukkan ke dalam botol yang telah berisi $45 \mathrm{ml}$ larutan (pepton water) PW lalu dihomogenkan sehingga diperoleh pengenceran $10^{-}$ ${ }^{1}$. Selanjutnya pengenceran dilakukan dengan cara yang sama pada pengenceran $10^{-2}, 10^{-3}$, dan $10^{-4}$. Pengenceran selesai dilakukan dan selanjutnya dilakukan pemupukan. Pemupukan dilakukan dari pengenceran $10^{-2}, 10^{-3}$, dan $10^{-4}$. Pemupukan dilakukan pada media EMBA. Setelah memadat, campuran diinkubasi selama 48 jam pada suhu $37^{\circ} \mathrm{C}$. Jumlah mikroba dihitung pada semua koloni yang tumbuh dalam setiap cawan petri.

\section{HASIL DAN PEMBAHASAN \\ Parameter Fisika}

Parameter fisika yang diuji adalah suhu, warna dan TDS (Total Dissolve Solid). Hasil pengujian suhu, warna dan TDS dapat dilihat pada Tabel 1 dan dibandingkan dengan baku mutu air kelas I berdasarkan Peraturan Gubernur Bali No. 16 Tahun 2016.

Tabel 1. Hasil Pengujian Parameter Fisika Kualitas Air Sungai Balian Bagian Hulu, Tengah, dan Hilir

\begin{tabular}{|c|c|c|c|c|c|c|}
\hline \multirow{2}{*}{ No. } & \multirow{2}{*}{ Parameter } & \multirow{2}{*}{ Satuan } & \multirow{2}{*}{ Baku Mutu*) } & \multicolumn{3}{|l|}{ Hasil } \\
\hline & & & & SI & SII & SIII \\
\hline 1 & Suhu & ${ }^{0} \mathrm{C}$ & Deviasi 3 & 26 & 25 & 26 \\
\hline 2 & Warna & - & $\begin{array}{l}\text { Tidak berwarna/ } \\
\text { jernih }\end{array}$ & $\begin{array}{l}\text { Agak } \\
\text { keruh }\end{array}$ & Jernih & $\begin{array}{l}\text { Agak } \\
\text { keruh }\end{array}$ \\
\hline 3 & TDS & $\mathrm{mg} / \mathrm{L}$ & 1000 & 630 & 550 & 510 \\
\hline
\end{tabular}

\section{Suhu Air Sungai Balian}

Sesuai dengan baku mutu air kelas I berdasarkan Peraturan Gubernur Bali No 16 Tahun 2016 yaitu Deviasi 3, hasil pengukuran suhu di ketiga lokasi titik sampling baik di bagian hulu, bagian tegah dan bagian hilir memiliki rata - rata $26,7^{\circ} \mathrm{C}$. Suhu suatu badan air dipengaruhi oleh musim, lintang, ketinggian dari permukaan laut, sirkulasi udara, penutupan awan, dan aliran serta kedalaman badan air (Effendi, 2003)

SI, SII, dan SIII dilakukan pada musim panas dimana intensitas cahaya sangat tinggi sehingga memungkinkan suhu pada badan air cukup tinggi seperti pada SI dan SIII yaitu $26{ }^{\circ} \mathrm{C}$. Sedangkan pada SII, pada pengukuran suhu lebih rendah daripada SI dan SII yaitu, $25^{\circ} \mathrm{C}$. Titik sampling SII berada di Banjar Sanda, Desa Sanda, Pupuan, Kab. Tabanan. Pada daerah ini, dilihat dari letak geografis Desa Sanda yang berada pada ketinggian 500-600 m dari permukaan laut, dengan curah hujan yang cukup tinggi, sehingga suhu pada badan air menjadi lebih rendah dari suhu titik sampling SI dan SIII.

\section{Warna Air Sungai Balian}

Pengukuran warna pada air di Sungai Balian pada penelitian ini, hanya melihat secara umum warna permukaan air (jernih/keruh). Hal ini disesuaikan dengan acuan baku mutu air kelas I berdasarkan Peraturan Gubernur Bali No. 16 Tahun 2016 dimana standarnya adalah jernih/tidak berwarna. 
Warna pada SI dan SIII agak keruh dipengaruhi oleh aktivitas masyarakat disekitar lokasi pengambilan sampel. Lokasi SI di daerah Banjar Bukittelu, Desa Bengkel, Busungbiu, Buleleng yang disampling berada di sekitar persawahan dan dekat dengan area peternakan liar, lokasi SIII di daerah Banjar Penyalin, Kerambitan, Tabanan kondisi air agak keruh dikelilingi bebatuan besar dan pohon besar. Sedangkan lokasi SII di daerah Banjar Sanda, Desa Sanda, Pupuan, Tabanan memiliki kondisi air yang jernih dengan dikelilingi sungai lebar, bebatuan besar dan umumnya digunakan sebagai tempat pembersihan dan upacara penyucian.

Berdasarkan hal tersebut, dilihat dari warna airnya maka air sungai pada titik SI dan SIII tidak cocok diperuntukkan sebagai air kelas 1 yaitu bahan baku air minum karena warna airnya sedikit keruh, sedangkan air sungai pada titik SII dapat digunakan sebagai bahan baku air minum.

\section{TDS (Total Dissolve Solid) Air Sungai Balian}

Parameter fisika lain yang diuji berupa residu terlarut (TDS). Padatan Terlarut Total (TDS) adalah bahan-bahan terlarut ( diameter $<10^{-6} \mathrm{~mm}$ ) dan koloid (diameter $10^{-6} \mathrm{~mm}$ hingga $10^{-3} \mathrm{~mm}$ ) yang berupa senyawa-senyawa kimia dan bahan- bahan lain yang tidak tersaring pada kertas saring berdiameter 0,45 $\mu \mathrm{m}$ (Rao, 1992).

TDS biasanya disebabkan oleh bahan anorganik berupa ion-ion yang biasa ditemukan di perairan misalnya Sodium (Na), Kalsium (Ca), Magnesium $(\mathrm{Mg})$, Bikarbonat $\left(\mathrm{HCO}_{3}\right)$, Sulfat $\left(\mathrm{SO}_{4}\right)$, Clorida $(\mathrm{Cl})$, Besi $(\mathrm{Fe})$, Strontium $(\mathrm{Sr})$, Kalium (K), Karbonar $\left(\mathrm{CO}_{3}\right)$, Nitral $\left(\mathrm{NO}_{3}\right)$, Fluorida (F), Boron (B) dan Silika $\left(\mathrm{SiO}_{2}\right)$ (Effendi, 2003).

Nilai TDS tertinggi adalah $630 \mathrm{mg} / \mathrm{L}$ yang berada pada lokasi SI, kadar TDS SII adalah 550 $\mathrm{mg} / \mathrm{L}$, dan SIII memiliki TDS $510 \mathrm{mg} / \mathrm{L}$ dengan rata-rata $563,3 \mathrm{mg} / \mathrm{L}$ masih dibawah ambang batas baku mutu air kelas I yaitu $1000 \mathrm{mg} / \mathrm{L}$. Nilai TDS perairan sangat dipengaruhi oleh pelapukan batuan, limpasan dari tanah, dan pengaruh antropogenik (berupa limbah domestik dan industri). Bahanbahan tersuspensi dan terlarut pada perairan alami tidak bersifat toksik, namun akan berpengaruh pada kekeruhan air yang selanjutnya berpengaruh terhadap proses fotosintesis di perairan (Effendi, 2003).

\section{Parameter Kimia}

Parameter kimia yang diuji adalah $\mathrm{pH}, \mathrm{BOD}_{5}$, COD, phosfat, dan nitrat. Hasil pengujian laboratorium terhadap kelima parameter tersebut dapat dilihat pada Tabel 2 .

Tabel 2. Hasil Pengujian Parameter Kimia Kualitas Air Sungai Balian Bagian Hulu, Tengah, dan Hilir

\begin{tabular}{|c|c|c|c|c|c|c|}
\hline \multirow{2}{*}{ No. } & \multirow{2}{*}{ Parameter } & \multirow{2}{*}{ Satuan } & \multirow{2}{*}{ Baku Mutu*) } & \multicolumn{3}{|l|}{ Hasil } \\
\hline & & & & SI & SII & SIII \\
\hline 1. & $\mathrm{pH}$ & - & $6-9$ & 7,23 & 7,03 & 7,78 \\
\hline 2. & $\mathrm{BOD}_{5}$ & $\mathrm{ppm}$ & 2 & 8,637 & 3,901 & 10,370 \\
\hline 3. & $\mathrm{COD}$ & ppm & 10 & 10,231 & 7,250 & 20,890 \\
\hline 4. & Phosfat & ppm & 0,2 & 0,122 & 0,096 & 0,237 \\
\hline 5. & Nitrat & ppm & 10 & 2,765 & 2,232 & 3,163 \\
\hline
\end{tabular}

\section{pH Air Sungai Balian}

Berdasarkan hasil pengujian laboratorium, $\mathrm{pH}$ air Sungai Balian, Tabananan, Bali masih sesuai dengan baku mutu. Berdasarkan ambang batas sesuai dengan Peraturan Gubernur Bali No. 16 Tahun 2016, secara keseluruhan hasil analisis kimia berupa $\mathrm{pH}$ masih normal, yaitu 7,03 - 7,78.

Untuk hasil analisi $\mathrm{pH}$, sampel air tanah berada dalam range batas normal kelas I yang digunakan untuk bahan baku air minum dan atau peruntukan lain yang mempersyaratkan mutu air yang sama, yaitu $\mathrm{pH}$ 6-9. $\mathrm{pH}$ air Sungai Balian di bagian tengah, dengan lokasi di Banjar Sanda, Desa Sanda, Pupuan, Tabanan memiliki pH sangat layak untuk air minum, yaitu $\mathrm{pH}$ 7,03. Dimana air sungai di bagian lokasi sampling digunakan oleh masyarakat Hindu untuk area pembersihan atau penyucian. Kondisi airnya juga sangat jernih. Keberadaan bebatuan di sepanjang aliran sungai tersebut juga membantu dalam mempurifikasi air sungai.

Sedangkan air Sungai Balian bagian hulu dilakukan di daerah Banjar Bukittelu, Desa Bengkel, Busungbiu, Buleleng kondisi airnya memiliki $\mathrm{pH} 7,23$ juga masih normal. Namun, kondisi air agak keruh, hal ini disebabkan karena aliran airnya merupakan daerah aliran persawahan yang diduga menghanyutkan sisa pupuk atau pestisida hasil aktivitas petanian. Namun, hasil pH juga normal untuk baku mutu kelas I.

Sedangkan air Sungai Balian bagian hilir dengan lokasi sampling di Banjar Penyalin, 
Kerambitan, Tabanan memilki $\mathrm{pH}$ yang masih normal, yaitu 7,78. Namun, hasil $\mathrm{pH}$ tersebut lebih tinggi dari bagian hulu dan tengah, tetapi keadaan tersebut wajar karena bagian hilir merupakan aliran air akumulasi dari bagian hulu dan tengah.

\section{BOD (Biology Oxigen Demand) Air Sungai Balian}

BOD (Biology Oxigen Demand) adalah jumlah oksigen yang dibutuhkan oleh mikroorganisme dalam mendegradasi bahan-bahan organik yang terdapat pada badan perairan. Secara keseluruhan, BOD air Sungai Balian tidak sesuai untuk baku mutu kelas I yang peruntukannya untuk air minum.

Air sungai bagian hulu memiliki BOD 8,637 yang masuk ke dalam katagori air kelas IV yang peruntukannya untuk pertanian. Tingginya BOD pada air Sungai Balian bagian hulu dikarenakan aliran air dari area persawahan yang membawa sisa-sisa pestisida dan pupuk yang hanyut terbawa oleh aliran sungai. Kondisi air yang berwarna agak keruh juga diperkirakan karena banyak terdapat peternakan yang kemungkinan membawa kotor peternakan yang kemungkinan membawa kotoran dari peternakan.

Pada air Sungai Balian bagian tengah memiliki BOD 3,901 yang masuk sebagai katagori air kelas II, dimana air tersebut dapat digunakan untuk air minum setelah diolah. Kondisi air yang jernih dan banyak dimanfaatkan oleh masyarakat Hindu untuk area penyucian dan pembersihan. Adanya bebatuan besar juga diperkirakan dapat sebagai biopori dalam proses penjernihan air Sungai Balian.

Bagian hilir sungai Balian memiliki BOD paling tinggi, yaitu 10,370 yang dapat dikatagorikan sebagai air kelas IV yang peruntukannya untuk pertanian dan pembangkit tenaga listrik. Tingginya BOD disebabkannya karena banyaknya jumlah bahan organik yang terdapat di badan perairan, sehingga semakin besar jumlah oksigen yang dibutuhkan oleh mikroorganisme tersebut untuk mempurifikasi badan peraiaran menjadi lebih tinggi.

Adanya pengaruh peningkatan suhu $1 \%$ juga mempengaruhi peningkatan konsumsi oksigen sebesar $10 \%$, dimana suhu air dibagian hilir pada bagian hilir sungai selalu lebih tinggi dibandingkan dengan bagian hulu dan tengah (Brown, 1987).

\section{COD (Chemical Oxygen Demand) Air Sungai Balian}

COD (chemical oxygen demand) adalah jumlah oksigen terlarut yang dibutuhkan oleh suatu mikroorganisme dalam mendegradasi bahan-bahan kimia yang terdapat pada badan perairan.
Berdasarkan hasil analisis, kadar COD Sungai Balian bagian hulu memiliki kadar COD 10,231 ppm. Hal ini menunjukkan bahwa nilai tersebut masih dapat dikatagorikan sebagai baku air mutu kelas I, yaitu yang diperuntukkan untuk air minum.

Untuk COD Sungai Balian di bagian tengah memiliki kadar COD 7,250 ppm yang masih berada di bawah air batas maksimal untuk air kelas I. dimana, berdasarkan Peraturan Gubernur Bali No. 16 Tahun 2016, baku mutu untuk kadar COD air kelas I adalah maksimum $10 \mathrm{ppm}$. Hal ini membuktikan bahwa COD air Sungai Balian bagian hulu dan tengah layak untuk digunakan sebagai sumber air minum.

Masih rendahnya kadar COD disebabkan karena jumlah cemaran dari bahan-bahan kimia yang terdapat pada badan perairan masih rendah. Sedangkan untuk air Sungai Balian bagian hilir memiliki kadar COD 20,890 ppm, hasil ini membuktikan bahwa air sungai bagian hilir dapat dikatagorikan sebagai air kelas II, yaitu dapat diperuntukkan sebagai air minum, namun harus melalui proses pengolahan.

Tingginya kadar COD air Sungai Balian bagian hilir daripada bagian hulu dan tengah disebabkan karena sungai bagian hilir sebagai daya tampung dari bagian, hulu, tengah, dan percabangan dari beberapa aliran sungai. Kondisi disekitar area sungai seperti adanya permukiman, warung-warung, dan beberapa home stay juga dapat meningkatkan COD karena adanya aliran limbah yang dibuang ke badan perairan.

\section{Phosfat Air Sungai Balian}

Phosfat bersumber dari hasil penggunaan deterjen dan pupuk pertanian yang mengandung bahan phosphor. Hasil analisis menunjukkan bahwa kadar phosfat air Sungai Balian bagian tengah dan hilir berada di bawah baku mutu yang diijinkan pada Peratuan Gubernur Bali No. 16 Tahun 2016, yaitu sebesar 0,2 ppm untuk air kelas I dan II sebagai air baku minum. Hasil phosfat air Sungai Balian bagian hulu 0,122 ppm dan 0,096 ppm untuk air Sungai Balian bagian tengah. Hal ini menunjukkan bahwa cemaran limbah yang mengandung phosfat masih sangat rendah.

Untuk air Sungai Balian bagian hilir memiliki kadar phosfat 0,237 ppm.Hasil ini sedikit berada diatas baku mutu air kelas I dan II. Hasil air ini tepatnya masuk sebagai air kelas III, yaitu yang peruntukannya untuk peternakan dan perikanan. Tingginya kadar phosfat air Sungai Balian bagian hilir daripada bagian hulu dan tengah disebabkan karena sungai bagian hilir sebagai daya tampung dari bagian, hulu, tengah, dan percabangan dari beberapa aliran sungai. Kondisi disekitar area sungai seperti adanya permukiman, warung- 
warung, dan beberapa home stay juga dapat meningkatkan phosfat karena adanya aliran limbah yang dibuang ke badan perairan, seperti phosfat dari deterjen, sabun, dan residu pupuk dari persawahan, baik yang di bagian tengah dan hilir.

\section{Nitrat Air Sungai Balian}

Parameter kadar nitrat pada perairan sungai dipersyaratkan sebesar $10 \mathrm{ppm}$ untuk air kelas I. Hasil pengukuran parameter nitrat air Sungai Balian 2,232-3,163 ppm. Hal ini menunjukkan adanya kegiatan perombakan bahan indicat yang mengandung $\mathrm{N}$ seperti protein yang terbawa sampai ke perairan hilir secara mikrobilogis. Ion nitrat $\left(\mathrm{NO}_{3}{ }^{-}\right)$merupakan salah satu ion yang banyak terdapat dalam air yang dihasilkan pada proses ferlilizer. Keberadaan nitrat bersama dengan phosfat yang tinggi dalam air dapat mengakibatkan pertumbuhan ganggang yang luar biasa yang juga disebut alga bloom. Namun, hasil analisis menunjukkan bahwa kadar nitrat masih dalam kondisi yang aman sehingga dapat dimanfaatkan untuk air baku minum.

\section{Parameter Mikrobiologi}

Parameter mikrobiologi yang diuji adalah E.coli dan total coliform. Hasil pengujian laboratorium terhadap kedua parameter tersebut dapat dilihat pada Tabel 3

Tabel 3. Hasil Pengujian Parameter Mikrobiologi Kualitas Air Sungai Balian Bagian Hulu, Tengah, dan Hilir

\begin{tabular}{|l|l|l|l|l|l|l|}
\hline \multirow{2}{*}{ No. } & \multirow{2}{*}{ Parameter } & \multirow{2}{*}{ Satuan } & \multirow{2}{*}{ Baku Mutu*) } & Hasil & SIII \\
\cline { 5 - 7 } & & & & SI & SII & SPN \\
\hline 1. & E. coli & MP0 MPN/100 mL & 30 & 15 & 89 \\
\hline 2. & Total coliform & MPN & $1000 \mathrm{MPN} / 100 \mathrm{~mL}$ & 50 & 25 & 100 \\
\hline
\end{tabular}

Parameter total coliform air Sungai Balian secara umum memenuhi persyaratan baku mutu dengan kadar yang dipersyaratkan. Adanya bakteri dalam air merupakan indikator adanya bahan pencemar kotoran manusia dan hewan berdarah panas. Adapun spesies dari bakteri tersebut adalah Escherischia coli. Adanya bakteri tersebut dalam jumlah yang tinggi dapat mengindikasikan adanya mikroorganisme berbahaya lainnya yang dapat menyebabkan penyakit seperti tipus dan hepatitis.

Hasil analisis secara mikrobiologi secara keseluruhan baik, E. Coli dan Total coliform sesuai dengan baku mutu air kelas I yang peruntukannya untuk sumber air minum baik yang langsung digunakan maupun harus dengan pengolahan. Dimana persyaratannya untuk E. Coli dan Total coliform adalah 100 MPN/ $100 \mathrm{~mL}$ sampel air.

\section{SIMPULAN}

Berdasarkan hasil penelitian dan pembahasan, maka dapat disimpulkan bahwa air Sungai Balian bagian hulu dan hilir dapat dikatagorikan sebagai air kelas III, hal ini dikarenakan parameter BOD yang tinggi yaitu 8,637 ppm dan 10,370 ppm. Untuk air Sungai Balian bagian tengah masuk dalam air kelas II yang peruntukannya untuk air minum setelah dilakukan pengolahan, karena parameter fisika, kimia, dan mikrobiologi tidak melebihi baku mutu air kelas II sesuai Peraturan Gubernur Bali No. 16 Tahun 2016. Oleh karena itu, berdasarkan hasil uji laboratorium air Sungai Balian bagian tengah layak dipergunakan sebagai sarana pembersihan dan pengobatan sesuai kepercayaan masyarakat Hindu.

\section{DAFTAR PUSTAKA}

Adiono. 1987, Air dan Kegunaannya, USU, Medan.

Brown,A.L., 1987, Freshwater Ecology, Heinemann Educational Books, London, 163 $\mathrm{p}$.

Effendi, Hefni. 2003, Telaah Kualitas Air. Kanisius, Yogyakarta.

Hadiwiyoto, S., 2004. Teori dan Prosedur Pengujian Mutu Secara Mikrobiologi. Liberty. Yogyakarta.

Peraturan Gubernur Bali No. 16 Tahun 2016 tentang Baku Mutu Lingkungan Hidup dan Kriteria Kerusakan Lingkungan.

SNI 01-3554-2006. Cara Uji Air Minum Dalam Kemasan. Badan Standarisasi Nasional. ICS 67.160 .20

Sutiyono, 2000. Baku Mutu Air. Gramedia. Jaka 
Artini N.P.R., Risky D.P., Fujiastuti N.K.M / Kesehatan Terpadu 2(1) (2018) 